Article

\title{
Fucoidan and Alginate from the Brown Algae Colpomenia sinuosa and Their Combination with Vitamin $C$ Trigger Apoptosis in Colon Cancer
}

\author{
Reem Al Monla ${ }^{1}$, Zeina Dassouki ${ }^{1}$, Nouha Sari-Chmayssem ${ }^{1}$, Hiba Mawlawi ${ }^{1}$ and Hala Gali-Muhtasib ${ }^{2,3, *(1)}$ \\ 1 AZM Center for Research in Biotechnology and Its Applications, Laboratory of Applied \\ Biotechnology (LBA3B), Doctoral School for Sciences and Technology, Lebanese University, \\ Tripoli 1300, Lebanon; reem.el-monla@umontpellier.fr (R.A.M.); zeina.dassouki@ul.edu.lb (Z.D.); \\ nouha.sari@hotmail.com (N.S.-C.); hiba.mawlawi@ul.edu.lb (H.M.) \\ 2 Department of Biology, American University of Beirut, Riad El Solh, Beirut 1107 2020, Lebanon \\ 3 Center for Drug Discovery, American University of Beirut, Riad El Solh, Beirut 1107 2020, Lebanon \\ * Correspondence: amro@aub.edu.lb; Tel.: +961-3973820; Fax: +961-1-350000 (ext. 3894)
}

Citation: Al Monla, R.; Dassouki, Z.; Sari-Chmayssem, N.; Mawlawi, H.; Gali-Muhtasib, H. Fucoidan and Alginate from the Brown Algae Colpomenia sinuosa and Their Combination with Vitamin C Trigger Apoptosis in Colon Cancer. Molecules 2022, 27, 358. https://doi.org/ $10.3390 /$ molecules 27020358

Academic Editors: Zipora Tietel, Hilal Zaid, Birgit Strodel and Olujide Olubiyi

Received: 10 December 2021

Accepted: 4 January 2022

Published: 6 January 2022

Publisher's Note: MDPI stays neutral with regard to jurisdictional claims in published maps and institutional affiliations.

Copyright: (C) 2022 by the authors. Licensee MDPI, Basel, Switzerland. This article is an open access article distributed under the terms and conditions of the Creative Commons Attribution (CC BY) license (https:// creativecommons.org/licenses/by/ $4.0 /)$.

\begin{abstract}
Brown seaweeds are producers of bioactive molecules which are known to inhibit oncogenic growth. Here, we investigated the antioxidant, cytotoxic, and apoptotic effects of two polysaccharides from the brown algae Colpomenia sinuosa, namely fucoidan and alginate, in a panel of cancer cell lines and evaluated their effects when combined with vitamin C. Fucoidan and alginate were isolated from brown algae and characterized by HPLC, FTIR, and NMR spectroscopy. The results indicated that highly sulfated fucoidans had higher antioxidant and cytotoxic effects than alginate. Human colon cancer cells were the most sensitive to the algal treatments, with fucoidan having an $\mathrm{IC}_{50}$ value $\left(618.9 \mu \mathrm{g} / \mathrm{mL}^{-1}\right)$ lower than that of alginate $\left(690 \mu \mathrm{g} / \mathrm{mL}^{-1}\right)$. The production of reactive oxygen species was increased upon treatment of HCT-116 cells with fucoidan and alginate, which suggest that these compounds may trigger cell death via oxidative damage. The combination of fucoidan with vitamin $C$ showed enhanced effects compared to treatment with fucoidan alone, as evidenced by the significant inhibitory effects on HCT-116 colon cancer cell viability. The combination of the algal polysaccharides with vitamin $C$ caused enhanced degeneration in the nuclei of cells, as evidenced by DAPI staining and increased the subG1 population, suggesting the induction of cell death. Together, these results suggest that fucoidan and alginate from the brown algae C. sinuosa are promising anticancer compounds, particularly when used in combination with vitamin C.
\end{abstract}

Keywords: fucoidan; alginate; apoptosis; reactive oxygen species; human colon cancer cells

\section{Introduction}

The marine environment is an exceptionally diverse reservoir comprised of nearly 250,000 species that produce numerous secondary compounds with extraordinary chemical and pharmacological effects [1]. The growing interest in marine macroalgae as a sustainable source of natural molecules is mainly due to their therapeutic effects against cancer [2]. Unlike toxic conventional chemotherapies, these marine products exert minimal side effects on healthy tissues [2]. In recent years, there has been growing interest in the polysaccharides present in cell walls of brown algae, including laminarins, alginates, and fucoidans, as these compounds have high potential for biological applications in functional foods as well as cosmeceutical and pharmaceutical bioproducts [3].

Fucoidans found in brown seaweeds cover a family of sulfated fucose-rich polysaccharides. They are made up of a backbone of $(1 \rightarrow 3)$ and / or $(1 \rightarrow 4) \alpha$-linked L-fucopyranose units [4]. Owing to their biofunctional properties, fucoidans are potent antitumor agents with numerous pharmaceutical applications [5]. Fucoidans have shown strong cytotoxicity against different cancer cell lines, including breast cancer (MCF-7), human skin melanoma 
(SK-MEL-28), and colon cancer (HCT-15, DLD1, WiDr) cells [6]. Fucoidans are also known to significantly reduce the toxicity of chemotherapy in patients with advanced and recurrent cancers [7] and are used as adjuvants in complex cancer treatments. Interestingly, dietary fucoidans and those from other brown algal species were found to enhance the anticancer effects of the chemotherapeutic drugs tamoxifen and lapatinib when used against a wide range of cancer cells and in mouse models of cancer [8,9].

Alginates are one of the most exploited natural polysaccharides for manufacturing value-added products and are widely used in the pharmaceutical industry $[10,11]$, Alginates are linear copolymers made of $\beta$-D-mannuronic acid $(\mathrm{M})$ and $\alpha$-L-guluronic acid $(\mathrm{G})$ bound in blockwise arrangements [12]. They have been shown to inhibit many cell lines including cervical (HeLa), hepatocellular (HepG2), breast (MDA-MB-231), and colon (HCT-116 and $\mathrm{CaCo}$ ) cancer cells [13-15]. Alginates were also found to protect human intestinal cells from carcinogenesis via their antioxidant effects and their ability to chelate heavy metals and toxins [16], and to act in combination with chitosan, bortezomib, and 5-Fluorouracil to inhibit cell proliferation [17-19].

Combination therapy of natural molecules is considered to be a promising strategy to boost the therapeutic efficacy of chemotherapeutics as well as reduce their toxicity and side effects [20]. High-dose vitamin $\mathrm{C}$ is safely employed as a complementary treatment against colon cancer [21]. Additionally, the combination of vitamin $C$ with multiple standard drugs and natural molecules resulted in significant inhibitory effects against cancer cell growth and proliferation [22,23].

Studies on the Lebanese algae against cancer are very limited, and they mostly rely on colorimetric methods [24-27]. C. sinuosa is a brown algae that was previously investigated by our team, and the results confirmed an elevated carbohydrate content in the tissues of this species [28]. The cytotoxic potential of fucoidans and alginates of C. sinuosa on different cancer cells have never been examined, and the effects of their combination with vitamin $C$ remains unknown. Thus, we studied the chemical properties as well as the antitumor and apoptotic potency of fucoidan and alginate from $C$. sinuosa alone and in combination with vitamin $\mathrm{C}$ against different cancer cell lines including colon (HCT-116), breast (MCF 7), and ovarian (HeLa) cancer cell lines.

\section{Results}

\subsection{Physicochemical Properties and Monosaccharide Composition of Fucoidan and Alginate}

The physicochemical characteristics of the extracted fucoidan and alginate of $C$. sinuosa are presented in Table 1. There was very low percentage of protein and phenol contaminants in the preparation of the isolated polysaccharides. To determine the degree of sulfation, the barium-chloride method was adopted, and the results showed that fucoidan was highly sulfated $(18.8 \%)$ more than alginate $(5.53 \%)$. Moreover, the percentage of D-glucuronic acid was much higher in alginate $(50 \%)$ than fucoidan $(3.8 \%)$ (Table 1$)$.

Table 1. Physicochemical characteristics of the purified fucoidan and alginate isolated from C. sinuosa.

\begin{tabular}{cccccc}
\hline Sample & Yield (\%) & Protein (\%) & Sulfate (\%) & $\begin{array}{c}\text { Phenol } \\
\text { (mg GAE/gDW) }\end{array}$ & $\begin{array}{c}\text { D-Glucuronic Acid } \\
\text { (\%) }\end{array}$ \\
\hline Fucoidan & $11.6 \pm 0.3$ & $1.88 \pm 1.1$ & $18.8 \pm 2.1$ & $0.045 \pm 0.01$ & $3.8 \pm 0.5$ \\
\hline Alginate & $13.6 \pm 0.4$ & $2.63 \pm 1.4$ & $5.53 \pm 2.6$ & $0.043 \pm 0.01$ & $50 \pm 0.7$ \\
\hline
\end{tabular}

Values are presented as mean \pm SD $(n=3)$; DW: dry weight; GAE/gDW: gallic acid equivalent per gram of dry weight.

The monosaccharide composition of the extracted polysaccharides showed that fucose is the main sugar present in fucoidan (67.4\%) (Table 2). We observed large differences in the relative proportions of the different monosaccharides in fucoidan and alginate polymers. The HPLC spectra of both fucoidan and alginate are shown in Supplementary Figures S1 and S2. 
Table 2. Monosaccharides composition of fucoidan and alginate of C. sinuosa determined by HPLCRI analysis.

\begin{tabular}{ccccccc}
\hline Sample & \multicolumn{5}{c}{ Monosaccharide Composition (\%) } \\
\hline & Glucose & Xylose & mannose & Arabinose & Galactose & fucose \\
\hline Fucoidan & $5.45 \pm 2.97$ & $2.62 \pm 2.12$ & $3.58 \pm 1.34$ & $3.4 \pm 1.39$ & $5.94 \pm 3.88$ & $67.4 \pm 12.1$ \\
Alginate & $2.67 \pm 3.59$ & $2.14 \pm 2.48$ & $5.11 \pm 2.64$ & $4.2 \pm 3.67$ & $4.98 \pm 4.66$ & $0.2 \pm 0.34$ \\
\hline
\end{tabular}

Values are presented as mean $\pm \mathrm{SD}(n=3)$.

\subsection{Brown Algal Polysaccharides Structural Analysis by FTIR}

Fucoidan FTIR spectrum (Figure 1) revealed that the primary absorptive peaks were a characteristic of glycosidic structures and were related to $\mathrm{C}-\mathrm{O}$ and $\mathrm{C}-\mathrm{C}$ stretching vibrations of the pyranoid ring $\left(1030 \mathrm{~cm}^{-1}\right)$ and the anomeric C-H group $\left(840 \mathrm{~cm}^{-1}\right)$. The FTIR spectrum of fucoidan also exhibited a broad peak at $3250-3500 \mathrm{~cm}^{-1}$ which was attributed to a hydroxyl stretching vibration. The two peaks at 2910 and $2989 \mathrm{~cm}^{-1}$ corresponded to the stretching vibration of the $\mathrm{C}-\mathrm{H}$ bond of the pyranoid ring and the C-6 group of fucose. The position of sulfate groups is contained in the ranges of $1500-700 \mathrm{~cm}^{-1}$. Furthermore, it has been reported that the broad signal at $1240 \mathrm{~cm}^{-1}$ (-S-O asymmetric stretching vibration of the sulfate group) is representative of the total sulfate esters in polysaccharides [29].

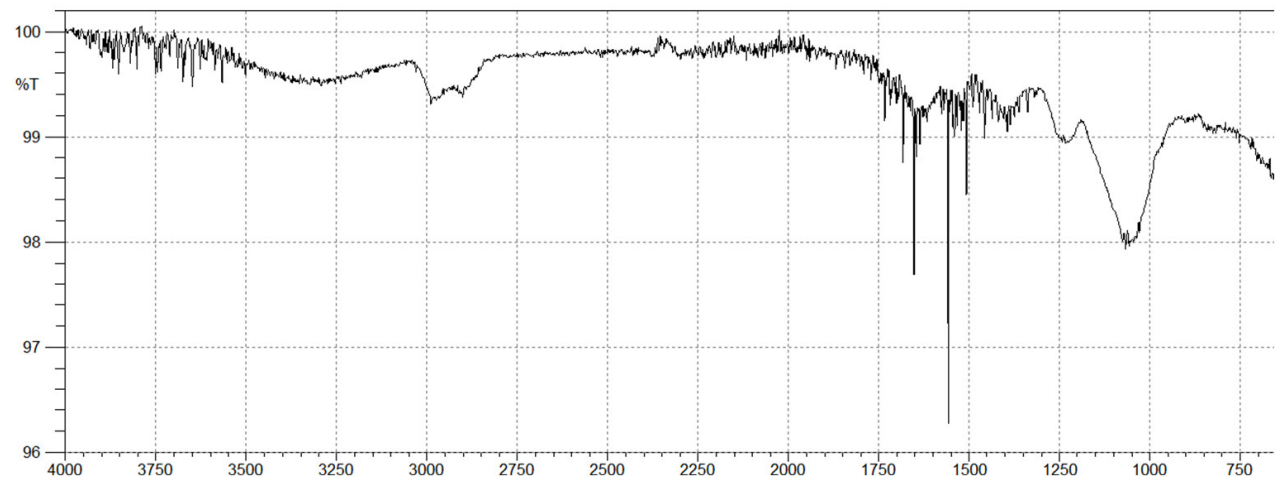

Figure 1. FTIR spectrum of fucoidan isolated from the Lebanese C. sinuosa.

The FTIR spectrum of alginate (Figure 2) showed a broad peak at $3280 \mathrm{~cm}^{-1}$ and a weak signal at $2910 \mathrm{~cm}^{-1}$, which are attributed to the stretching vibrations of hydroxyl groups $\mathrm{O}-\mathrm{H}$ and $\mathrm{C}-\mathrm{H}$, respectively. The two strong bands at 1620 and $1400 \mathrm{~cm}^{-1}$, are assigned to asymmetric and symmetric stretching vibrations of carboxyl groups of alginates. The band at $948 \mathrm{~cm}^{-1}$ corresponds to $\mathrm{C}-\mathrm{O}$ stretching vibration of uronic acid residues and the small band at $904 \mathrm{~cm}^{-1}$ corresponds to C-C of $\alpha$-L guluronic acid. In spectral analysis, the presence of a band at $1031 \mathrm{~cm}^{-1}$ was slightly more intense than the other band at $1085 \mathrm{~cm}^{-1}$ (M blocks), suggesting that the obtained alginate is slightly richer in guluronic residues.

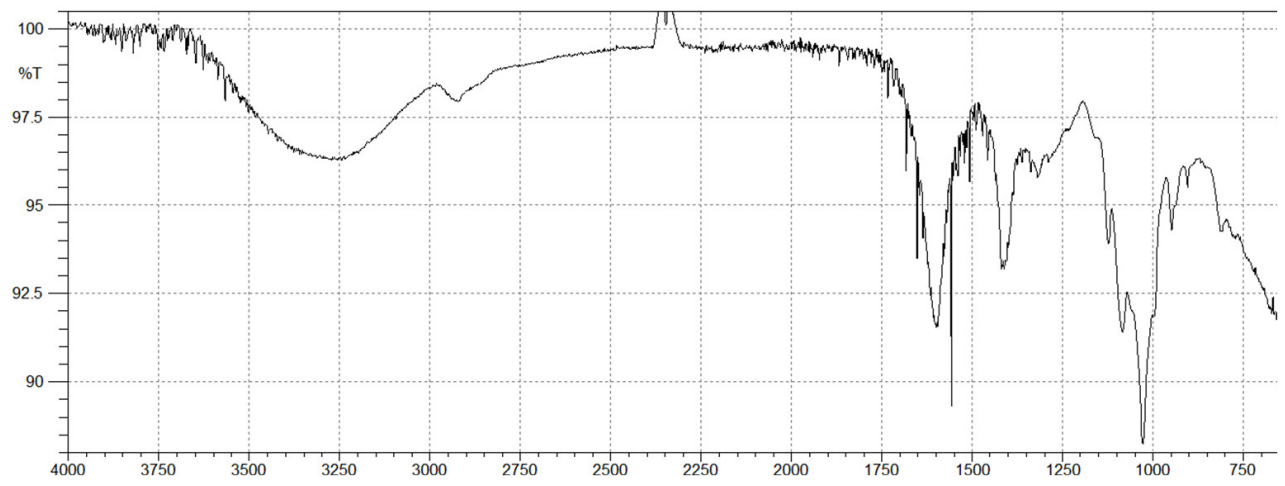

Figure 2. FTIR spectrum of alginate isolated from the Lebanese C. sinuosa. 


\subsection{Structural Characterization of Algal Polysaccharides by NMR Spectroscopy}

${ }^{1} \mathrm{H}$ NMR spectroscopy is the most reliable method used for the investigation of chemical composition and structural patterns. The proton spectrum of fucoidan from C. sinuosa (Figure 3) contained chemical shifts ranging from 5 to $5.5 \mathrm{ppm}$, which are attributed to anomeric protons $(\mathrm{H}-1)$ of $\alpha$-linked-L-fucose and $\beta$-linked sugars. The presence of intense peaks of the methyl groups were observed between 0.8 and $1.4 \mathrm{ppm}$. This chemical shift showed the specificity of methylated protons $\left(\mathrm{CH}_{3}\right)$ at the C-6 position of L-fucose. Monosaccharides generally do not have alkyl groups; therefore, the chemical shifts were in the range of 3.5-4.5 ppm instead of $1 \mathrm{ppm}$. The spectrum also contained resonance characteristics of L-fucopyranose ring protons (H-2 to H-5) ranging between 3.5 and $4.5 \mathrm{ppm}$. These signals confirmed the presence of different types of fucose-sulfated groups with changes in glycosidic linkage positions and monosaccharide patterns.

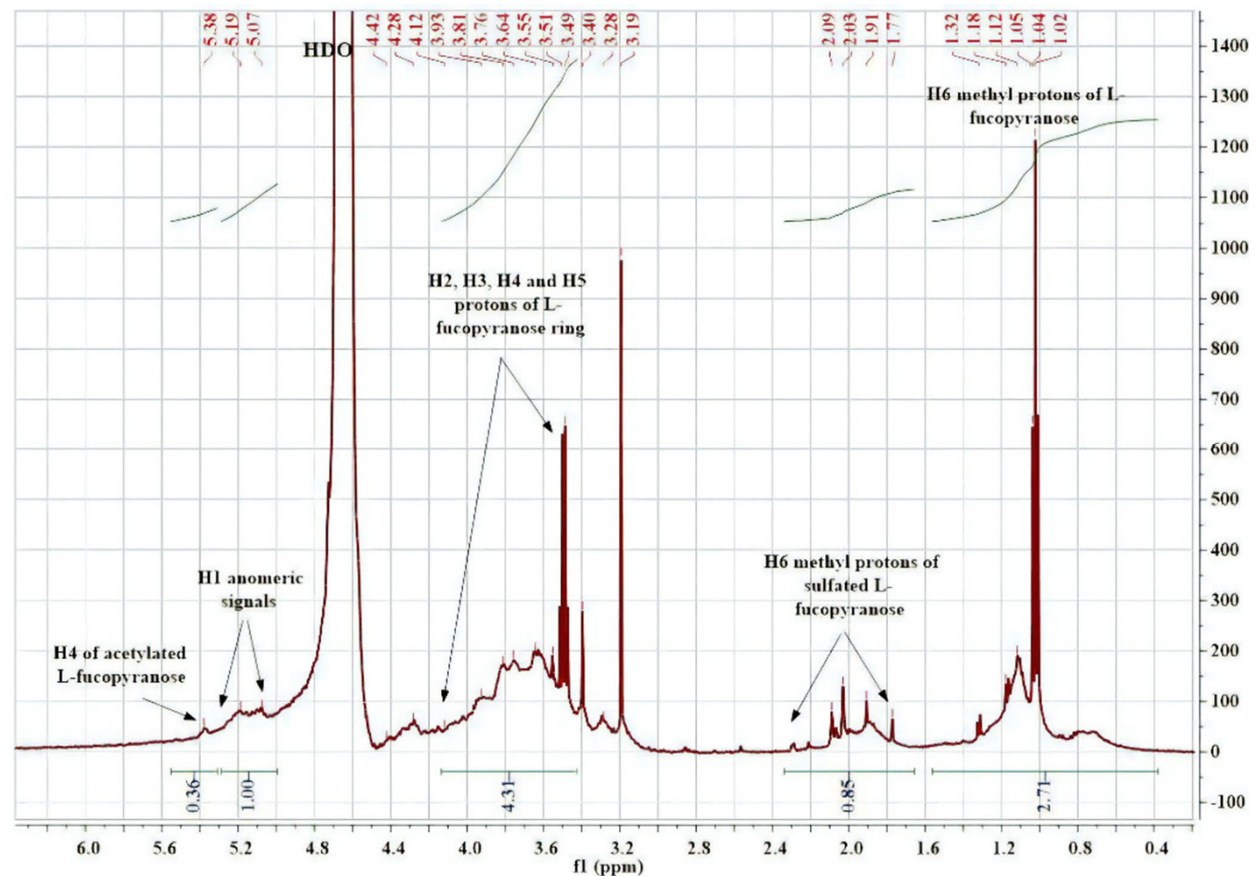

Figure $3 .{ }^{1} \mathrm{H}$ NMR spectrum of the extracted fucoidan polysaccharide.

To characterize the composition and $\mathrm{M} / \mathrm{G}$ ratio of the extracted alginate, the approach of Grasdalen was adopted [30]. The relative areas of the peak I at $5.11 \mathrm{ppm}$ (guluronic anomeric proton G-1), peak II at 4.71 ppm (mannuronic anomeric proton M-1 and the C-5 of alternating blocks GM-5), and peak III at $4.50 \mathrm{ppm}$ (H-5 guluronic residue G-5) encompass information on the uronic acid composition and fractions of nearest neighbors along the copolymer chain [30-32] (Figure 4).

Numerical values for the uronic acid composition, $M / G$ ratio, and doublet frequencies of the extracted alginate are presented in Table 3. The $M / G$ ratio value of alginate was 0.41 , indicating that alginate extracted from $C$. sinuosa has a higher fraction of guluronate in comparison to mannuronate. Additionally, alginate exhibited a higher $\mathrm{G}$ monomer (0.71) and dimer GG (0.65) than that of M monomer (0.29) and dimer MM (0.23) (a dimer is an oligomer consisting of two monomers joined by bonds). The ${ }^{1} \mathrm{H}$ and ${ }^{13} \mathrm{C}$ NMR chemical shifts of the purified alginate and fucoidan are shown in Supplementary Table S1. 


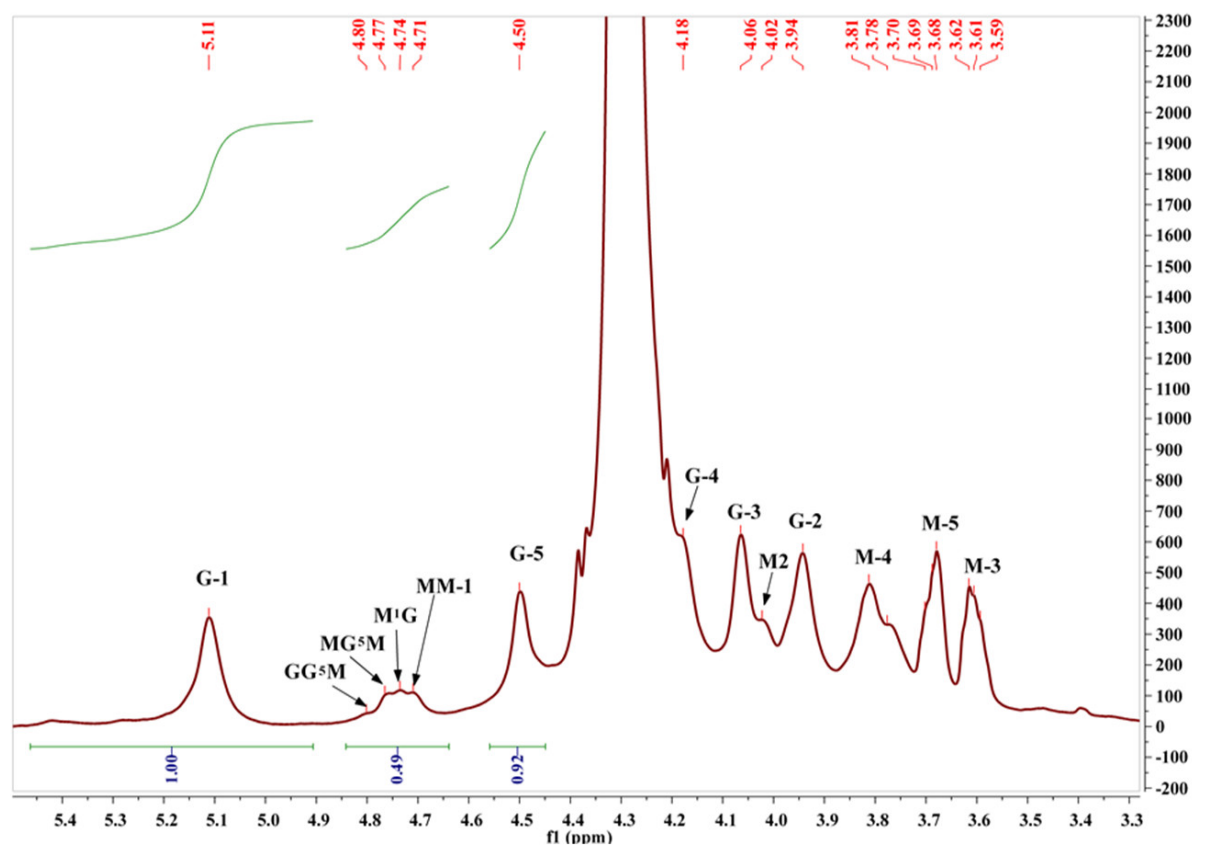

Figure 4. ${ }^{1} \mathrm{H}$ NMR spectrum of the extracted alginate.

Table 3. Numerical values for the uronic acid composition, $M / G$ ratio, and doublet frequencies of alginate extracted from C. sinuosa.

\begin{tabular}{ccccccc}
\hline Numeric Values & $\mathbf{F}_{\mathbf{G}}$ & $\mathbf{F}_{\mathbf{M}}$ & $\mathbf{M} / \mathbf{G}$ Ratio & $\mathbf{F}_{\mathbf{G G}}$ & $\mathbf{F}_{\mathbf{G M}}=\mathbf{F}_{\mathbf{M G}}{ }^{*}$ & $\mathbf{F}_{\mathbf{M M}}$ \\
\hline Alginate & 0.71 & 0.29 & 0.41 & 0.65 & 0.06 & 0.23
\end{tabular}

${ }^{*} \mathrm{~F}_{\mathrm{GM}}$ refers to the frequency of the dimer formed by guluronate-mannuronate; $\mathrm{F}_{\mathrm{GM}}$ refers to the frequency of the dimer formed by mannuronate-guluronate.

\subsection{C. sinuosa Polysaccharides Exhibited Antioxidant Activities}

To evaluate the antioxidant activity of isolated polysaccharides, it is recommended to use more than one assay [33]. 2,2-diphenyl-1-picryl-hydrazyl-hydrate (DPPH) assay was first used as it is an accurate, easy, and economic method to determine the radical scavenging activity of antioxidants [34]. The activity of superoxide dismutase (SOD) was also measured in the presence of fucoidan and alginate as this is one of the most important and sensitive antioxidant enzymes [35]. Fucoidan and alginate both demonstrated dosedependent antioxidant activities, as shown in Figure 5.

Fucoidan displayed a higher antioxidant capacity than alginate in both the DPPH and SOD assays. Fucoidan treatment increased the antioxidant SOD activity, as evidenced by the inhibition of water-soluble tetrazolium salt, to a greater extent $(90.7 \pm 4.4 \%$ at $\left.750 \mu \mathrm{g} / \mathrm{mL}^{-1}\right)$ than alginate $(86 \pm 0.7 \%)$ (Figure 5A). The SOD IC 50 value of fucoidan was lower than that of alginate $\left(23.7 \pm 1.1\right.$ and $41.34 \pm 1.07 \mu \mathrm{g} / \mathrm{mL}^{-1}$, respectively). We then compared the DPPH scavenging activity of fucoidan and alginate to the known antioxidant compound gallic acid (Figure 5B). Fucoidan possessed a significantly higher scavenging activity $\left(89 \% \pm 0.4 \%\right.$ at $\left.750 \mu \mathrm{g} / \mathrm{mL}^{-1}\right)$ than alginate $(61.6 \pm 0.5 \%)$, and slightly lower activity than gallic acid $(97.2 \pm 1.6 \%)$. The DPPH IC 50 value of fucoidan was also lower than that of alginate $\left(46.2 \pm 1.4\right.$ and $280 \pm 1.2 \mu \mathrm{g} / \mathrm{mL}^{-1}$, respectively). 
A

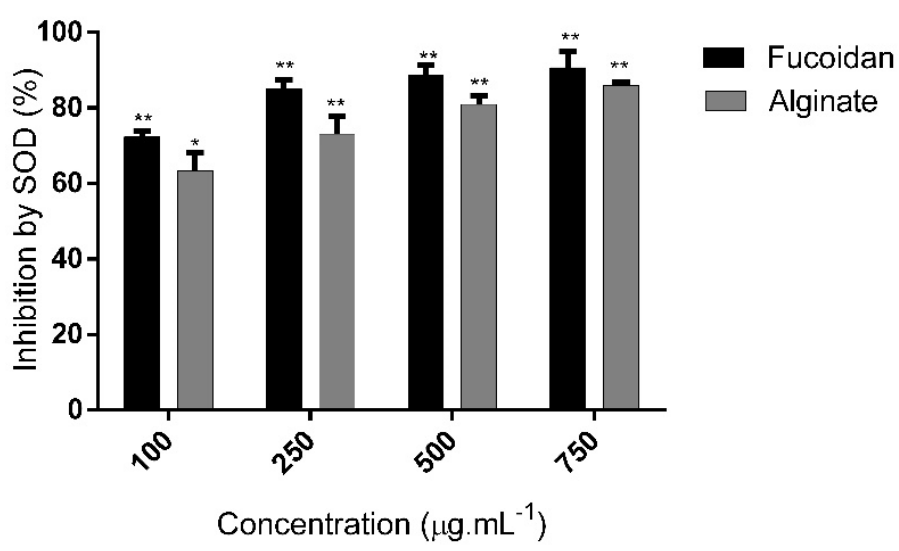

B

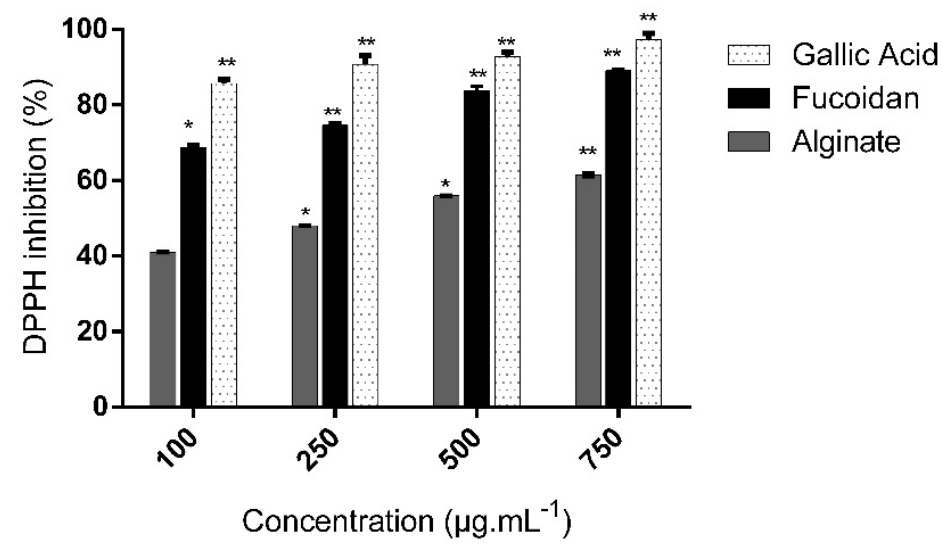

Figure 5. Antioxidant activity of C. sinuosa polysaccharides at four different concentrations $\left(100-750 \mu \mathrm{g} / \mathrm{mL}^{-1}\right)$ (A) Percentage inhibition of tetrazolium salts by SOD present in fucoidan and alginate (B) DPPH free radicals scavenging activity (\% inhibition) of fucoidan and alginate (mean $\pm \mathrm{SD} ; n=3)$. Significant differences are indicated as ${ }^{*} p<0.05$ and ${ }^{* *} p<0.01$ with respect to control.

\subsection{C. sinuosa Polysaccharides Showed Potent Antitumor and ROS-Inducing Effects against HCT-116 Colon Cancer Cells}

First, we examined the antitumor properties of the extracted polysaccharides by exposing colon HCT-116, cervical HeLa, and breast MCF 7 cells to different concentrations, and then determined their effect on cell viability using MTT assay. We observed dose and time inhibitory effects of both compounds on cell viability at 24 and $48 \mathrm{~h}$ (Figure 6).

There was a significant decrease in cell viability in HCT-116 cells treated for $24 \mathrm{~h}$ at high concentrations of fucoidan ( $45 \%$ inhibition at $750 \mu \mathrm{g} / \mathrm{mL}^{-1}$, Figure $\left.6 \mathrm{~A}\right)$ in comparison to low concentrations $\left(11.5 \%\right.$ cell inhibition at $\left.100 \mu \mathrm{g} / \mathrm{mL}^{-1}\right)$. Similar dose-dependent inhibition patterns were observed upon treatment with alginates, with $37.1 \%$ inhibition observed at $750 \mu \mathrm{g} / \mathrm{mL}^{-1}$ (Figure 6C). The viability of HCT-116 colon cancer cells treated with $750 \mu \mathrm{g} / \mathrm{mL}^{-1}$ of fucoidan at $48 \mathrm{~h}$ was lower than MCF 7 and the HeLa cell lines (Figure 6B). Similar results were obtained with alginate treatments on the selected cancer cell lines (Figure 6D). Thus, the HCT-116 cell line was the most sensitive to the polysaccharides, with fucoidan having an $\mathrm{IC}_{50}$ value $\left(618.9 \mu \mathrm{g} / \mathrm{mL}^{-1}\right)$ lower than that of alginate $\left(690 \mu \mathrm{g} / \mathrm{mL}^{-1}\right)$ (Supplementary Table S2).

The induction of apoptosis by ROS is considered to be a central mechanism in cancer therapy, and several recent approaches for colon cancer treatment are based on modulating ROS levels [36]. To investigate mechanisms involved in cell death, we used the fluorescent probe DCFDA to quantify ROS production in the most sensitive cell line HCT-116 upon treatment with fucoidan and alginate. As shown in Figure 7, treatment with fucoidan and alginate triggered a significant generation of intracellular ROS in comparison to control, suggesting that the induction of ROS is an important event in the cell death mechanism caused by these marine polysaccharides. 
A

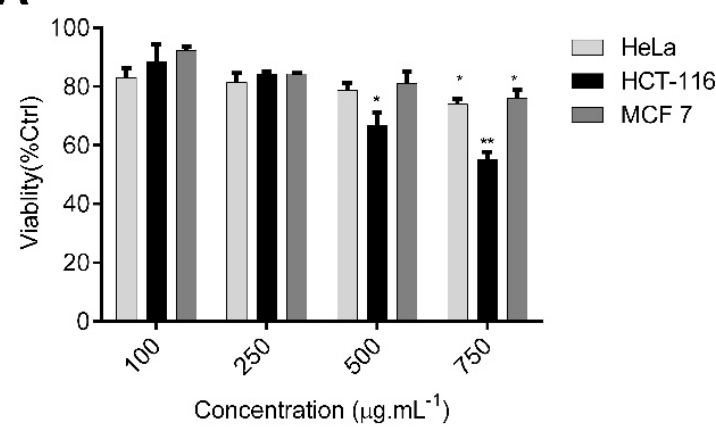

C

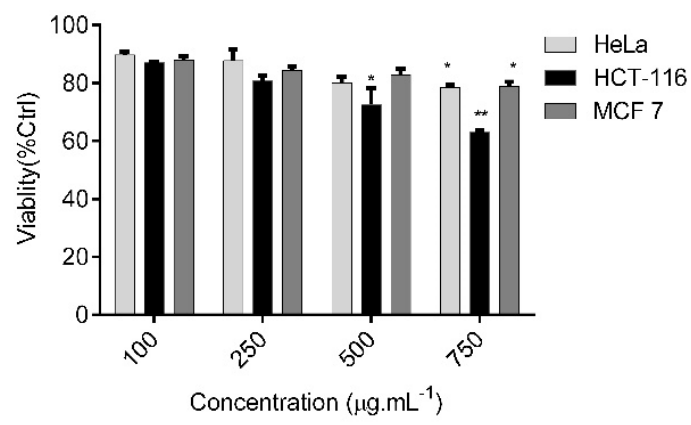

B

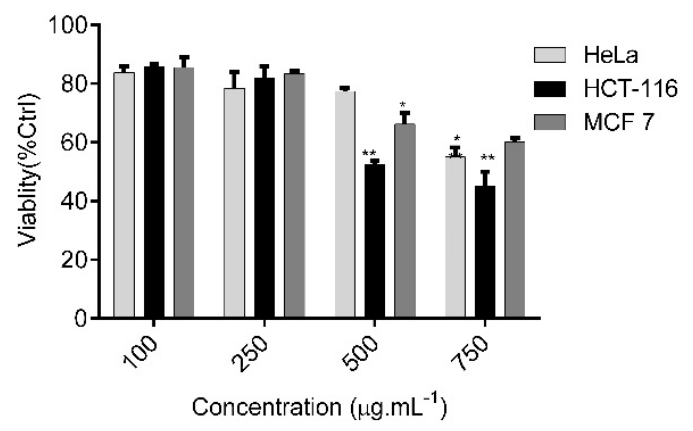

D

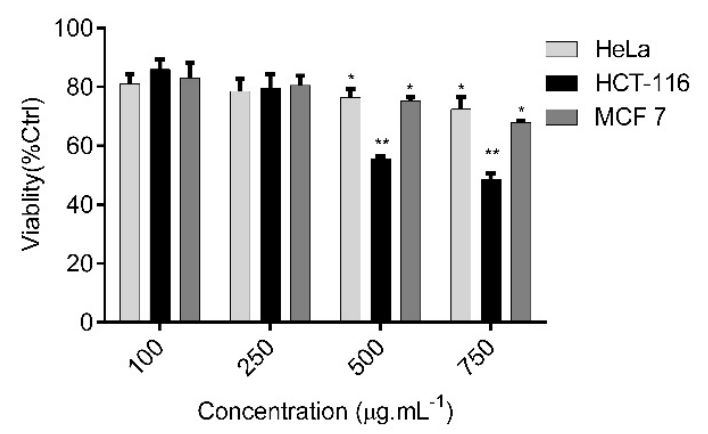

Figure 6. Cytotoxic effects of fucoidan and alginate on the viability of various cancer cells (HCT-116, MCF 7, and HeLa). Different concentrations of fucoidan on tumor cells were tested at $24 \mathrm{~h} \mathrm{(A)}$ and $48 \mathrm{~h}$ (B). Cytotoxic potentials of alginate against these cancer cell lines were also examined at $24 \mathrm{~h}(\mathrm{C})$ and $48 \mathrm{~h}(\mathrm{D})$ (mean $\pm \mathrm{SD} ; n=3$ ). Significant differences are indicated as ${ }^{*} p<0.05$ and ${ }^{* *} p<0.01$ with respect to control.

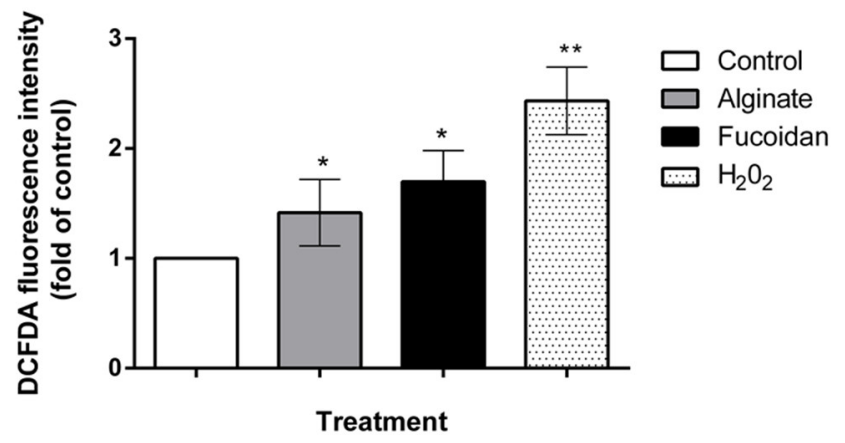

Figure 7. Fucoidan and alginate isolated from C. sinuosa trigger an increase in DCFDA fluorescence intensity, reflecting the enhanced ROS levels in HCT-116 colon cancer cells (mean $\pm \mathrm{SD} ; n=3$ ). Significant differences are indicated as $*<0.05$ and ${ }^{* *} p<0.01$ with respect to control.

2.6. Combination Treatment of Vitamin C and C. sinuosa Polysaccharides Significantly Increase the Cytotoxic Activity against HCT-116 Cancer Cells

Since the purified fucoidan and alginate of $C$. sinuosa were mostly effective against HCT116 cells, we assessed their effects at two different concentrations $\left(500\right.$ and $750 \mu \mathrm{g} / \mathrm{mL}^{-1}$ ) in combination with $5 \mathrm{mM}$ vitamin $\mathrm{C}$ at 24 and $48 \mathrm{~h}$. We tested whether the combined treatments resulted in enhanced cytotoxicity with respect to single treatments (Figure 8A,B). 
A

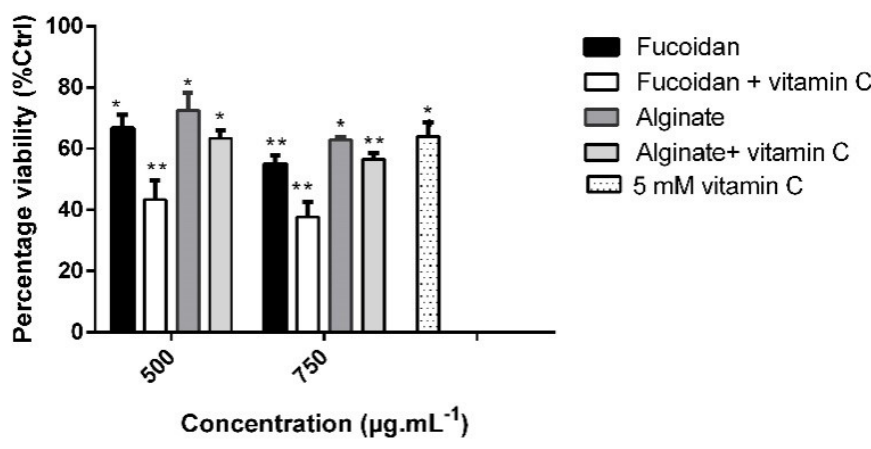

$\mathrm{B}$

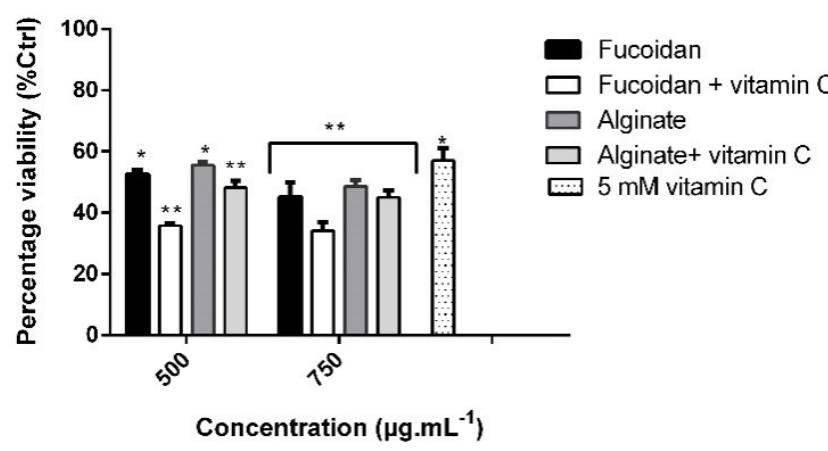

Figure 8. Influence of polysaccharides from C. sinuosa at two different concentrations and their combination with vitamin C on HCT-116 cell viability after (A) $24 \mathrm{~h}$ and (B) $48 \mathrm{~h}$ incubation (mean \pm SD; $n=3$ ). Significant differences are indicated as $* p<0.05$ and ${ }^{* *} p<0.01$ with respect to control.

As shown in Figure 8B, the combination of $5 \mathrm{mM}$ vitamin $C$ with $750 \mu \mathrm{g} / \mathrm{mL}^{-1}$ of fucoidan at $48 \mathrm{~h}$ resulted in a significant reduction in cell viability (34.2\%), in comparison to either compound alone (45 and $57 \%$ decrease in presence of fucoidan or vitamin C, respectively). The decrease in HCT-116 cell viability when treated with alginate and vitamin C was almost similar ( $45 \%$ at $48 \mathrm{~h}$ ) to alginate treatment alone $(48.6 \%)$. Thus, the combination of vitamin $C$ with fucoidan appears to display a more potent antitumor effect than combining vitamin $C$ with alginate.

\subsection{Combination of Vitamin C and Algal Polysaccharides Trigger Cell Cycle Regulation and Morphological Alterations in HCT-116 Cells}

To examine whether the inhibition of viability by the combination treatment was due to cell cycle arrest and/or apoptosis, cell cycle analysis was performed using propidium iodide (PI) staining of DNA followed by flow cytometry. Treatment of HCT-116 cells with fucoidan and alginate alone or in combination with vitamin $C$ yielded a significant accumulation of cells in the sub G1 phase of the cell cycle in comparison to control (28.5\%) (Figure 9A).

The number of cells in the G1 phase decreased significantly from 35\% in control to almost $17 \%$ after treatment with fucoidan alone or its combination with vitamin $\mathrm{C}$ (Figure 9A). The percentage of cells in the G1 phase also decreased post alginate treatment, particularly when alginate was combined with vitamin $C$. These results indicate that fucoidan and alginate (alone or in combination with vitamin C) induce cell death in HCT116 cancer cell line. Separation and gating of the different phases of the cell cycle are given in Figure S3.

To investigate the cell death mechanism by fucoidan and alginate, we analyzed the morphological changes observed in the nuclei of treated HCT-116 cells using DAPI staining (Figure 9B). Apoptosis is known to cause different morphological changes in cells, which include cell shrinkage, cytoplasm, nuclear and chromatin condensation, and nuclei degradation into discrete particles [37]. Apoptotic features were observed in microscopic images 
of HCT-116 cells after $24 \mathrm{~h}$ of treatment with $750 \mu \mathrm{g} / \mathrm{mL}^{-1}$ fucoidan, alginate, and vitamin C (5 mM) combinations. Both polysaccharides caused cellular changes which included cell shrinkage, discrete particles, and chromatin and cytoplasmic condensations (Figure 9B). Thus, flow cytometry analysis and DAPI staining both suggested the possible induction of apoptosis in HCT-116 cells in response to fucoidan and alginate treatment.

A

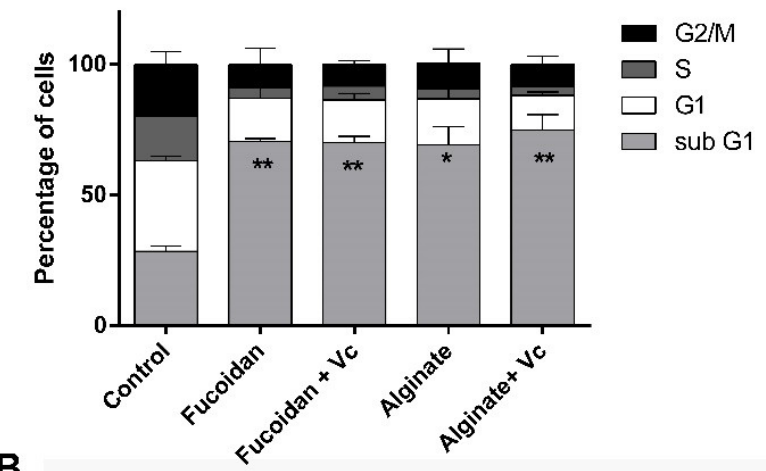

B

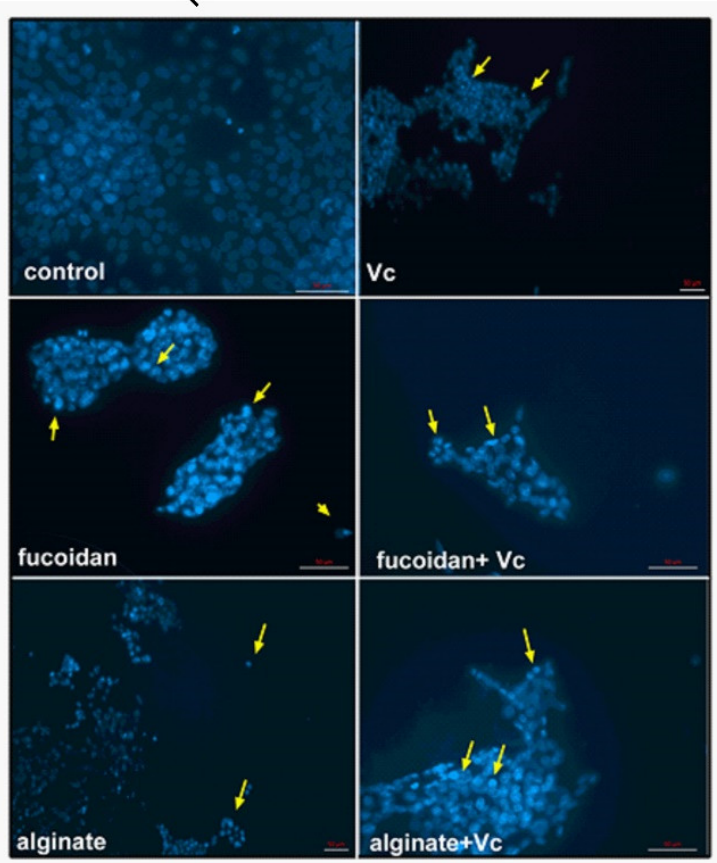

Figure 9. Cell cycle and morphological analysis of HCT-116 colorectal cancer cells treated with fucoidan, alginate, and their combination with vitamin C (A) Flow cytometry analysis shows the effects of fucoidan, alginate, and their combination on the cell cycle progression at $24 \mathrm{~h}$; (B) DAPI micrographs of HCT-116 cells indicated that nuclear fragmentation and chromatin condensation occurred in vitamin $\mathrm{C}$, fucoidan, and alginate-treated cells alone or with vitamin $\mathrm{C}$ combination. Nuclei were counterstained with DAPI (blue), scale bars $=50 \mu \mathrm{m}$. Significant differences vs. control cells, comparing cell cycle phases (SubG1, G0/G1, S, G2/M), are indicated as * $p<0.05$ and ${ }^{* *} p<0.01$ with respect to control.

\section{Discussion}

Marine polysaccharides have numerous anticancer properties that make them interesting candidates for integration in drug discovery and biomedical applications [38]. In our previous study, the elemental, organic composition, and phenolic content of C. sinuosa extract was determined [28]. The apoptotic effects of the crude phenol-rich extracts of this algae were then tested against colon cancer [39] without characterizing the chemical structure of the components. Considering that the polysaccharides of $C$ sinuosa are the most abundant components [28], we hereby characterized the fucoidan and alginate 
polysaccharides present in this algae and studied their anticancer activity alone and in combination with vitamin $C$ against a panel of solid tumors. Alginates and fucoidans are known to be safe to normal cells, as they are also available in dietary supplements [40]. To our knowledge, fucoidans and alginates extracted from $C$. sinuosa and their combination with vitamin $C$ have never been evaluated for their anticancer activity. Previous studies documenting the cytotoxic effects of polysaccharides from Lebanese brown algae were only based on MTT assays rather than on mechanistic biological approaches that could allow meaningful comparisons. Thus, this is the first report that documents the use of the Lebanese macroalgal polymers as natural medicinal sources of anticancer biomolecules in combination with vitamin $C$.

Since structural variations play a major role in determining the biological properties of a polymer, we first studied the structure of the isolated polysaccharides from the Lebanese C. sinuosa [10]. The FTIR spectra revealed two strong bands at 1620 and 1400, assigned to asymmetric and symmetric stretching vibrations of carboxyl groups of alginates. The anomeric region of this carbohydrate, between 950 and $750 \mathrm{~cm}^{-1}$, is the most discussed in the literature [41]. The presence of a band at $815 \mathrm{~cm}^{-1}$ in the alginate spectrum is attributed to mannuronic acid residues [42]. The guluronic units showed a band at approximately $1031 \mathrm{~cm}^{-1}$, higher than that of mannuronic units at $1085 \mathrm{~cm}^{-1}$ [43].

It is also well known that sodium alginate is a linear macromolecule composed of poly-

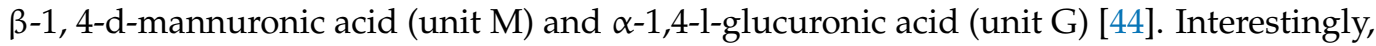
the alginates isolated from $C$. sinuosa were richer in guluronic than mannuronic acid, indicating that these alginates can form strong and heat-stable hydrogels. This is because the guluronate blocks allow a high degree of divalent ion coordination, which is essential for enhancing gelling properties [45]. However, it must be noted that the structure of the alginate extracted from the Lebanese C. sinuosa is slightly different from alginates present in brown algae of other species in the same region. For instance, the alginate we extracted had lower $\mathrm{M} / \mathrm{G}$ ratio (0.41) than those extracted from Sargassum vulgare (0.78) and Stypopodium schimperi (0.96) [46,47]. Additionally, most fucoidans of brown seaweeds consist mainly of sulfated L-fucose (about 34-44\%) [48], which is in parallel with our physicochemical analysis showing the elevated levels of fucose. The structure of fucoidan was further validated by the IR spectra indicating that the isolated fucoidan had close structural similarity to commercial fucoidan $[49,50]$. The profiles of the proton NMR spectrum of fucoidans from C. sinuosa were similar to several other fucoidans extracted from different origins and were comparable to fucoidans reported in Stypopodium schimperi growing on the Lebanese coast [47,51-53].

Establishing consistent bioactivities for fucoidan and alginate is a challenge because of variations in extraction methods, species-related structural diversity, growth conditions, harvest season, among other factors [54]. To a large extent, the bioactivity of these biopolymers is correlated with their structural characteristics. Alginate is recognized as an ideal candidate for chemical functionalization, and this is mainly due to the free hydroxyl and carboxyl groups distributed along the backbone, which allows the polymer to be modified and improve physicochemical and biological features [55]. It is known that the antioxidant potential of acidic polysaccharides is strongly related to their uronic acid content [56]; thus, the strong antioxidant activity of the extracted alginate could be attributed to their higher uronic acid content. Based on the literature, a higher sulfation degree has been tightly correlated with augmented bioactivity responses, including antioxidant potential [57]. The sulfate content of $C$. sinuosa fucoidan $(18.8 \%)$ appeared to be higher than that of commercial fucoidan $(14.4 \%)$, sargassum $(4.7 \%)$, and padina $(8.8 \%)$, but slightly lower than that of turbinaria species (19.4\%) [58]. Thus, the stronger antioxidant potential of fucoidans of C. sinuosa could be attributed to their higher sulfate content. When comparing the isolated fucoidan in this study to those extracted from different algal species elsewhere, we found that fucoidans of C. sinuosa had the highest DPPH scavenging potential [59-62].

Previous in vitro and in vivo studies have shown that algal polysaccharides exert antitumor effects, and suppress growth, angiogenesis, and metastasis in a range of cancer 
cells [63]. The cytotoxic potential of fucoidan and alginates isolated from S. schimperi revealed lower cytotoxicity on colon cancer cell lines compared to extracts from C. sinuosa [47]. Moreover, fucoidans of Lebanese origin isolated from Dictyopteris and Sargassum species exerted significant cytotoxic potential on human melanoma cells [64]. In this study, alginate and fucoidan of $C$. sinuosa were tested against different types of solid tumors, and the colon cancer HCT-116 cell line was found to be the most sensitive.

Furthermore, the ROS levels in HCT-116 cells were elevated upon treatment with polysaccharides from C. sinuosa. This increase in ROS was more pronounced upon fucoidan treatment (1.7-fold). This is in accordance with other studies that have shown that fucoidans from different algal species induce apoptosis in cancer cells via ROS-mediated cell signaling [65-68]. In addition, the combination of alginate with vanadyl [69] or with tamoxifen [70] was found to induce ROS-dependent cell death in cancer cells.

Many investigations have highlighted the importance of marine polysaccharides as candidates for combination therapy [8,71]. However, so far, only one study has investigated the effect of a mixture of dietary fucoidan from Japanese Mozuko seaweed with sodium ascorbic acid, and the results confirmed that this combination had strong antioxidant activity which was associated with an enhanced inhibition of fibrosarcoma tumor invasion in vitro [72]. In our study, the combination of vitamin $C$ with fucoidan and alginates ( $\mathrm{IC}_{50} 437.4$ and $453.3 \mu \mathrm{g} / \mathrm{mL}^{-1}$, respectively) acted synergistically to significantly increase cytotoxicity against colorectal cancer cells. This combination significantly decreased the $\mathrm{IC}_{50}$ of the isolated fucoidan to lower levels than fucoidans isolated from other regions and sources [6].

To unravel the mechanisms of cell death induced by the polysaccharides of $C$. sinuosa, their effects on the morphology and cell cycle regulation of HCT-116 cells were evaluated by flow cytometry and DAPI staining. Apoptosis is a major control mechanism in living organisms, and its deregulation results in cancer development; thus, the induction of apoptotic cell death in cancer cells is an effective strategy for cancer cell eradication [73]. Fucoidan, alginate, and their combination with vitamin $C$ revealed a significant increase in the proportion of cells present in the sub G1 phase. This reflects a typical cell death pattern [74], which was confirmed to be apoptosis by the morphological changes and apoptotic features revealed by DAPI staining. Other studies have shown that fucoidans extracted from different origins induced similar cell cycle alterations in MCF 7, HCT-116, and Caco cancer cell lines, as evidenced by the increase in the proportion of cells in the sub G1 phase and apoptosis induction via ROS-dependent mechanisms [68,75,76].

In conclusion, this study provides new insights for the use of marine polysaccharides from Lebanese brown algae as natural medicinal sources. Fucoidan and alginates from C. sinuosa appear to have promising antitumor activity against different human cancer cell lines. Their combination with vitamin $C$ caused enhanced cell cycle alterations, ROS generation, and apoptotic cell death in HCT-116 colon cancer cell line. Henceforth, fucoidans and alginates could be used in combination with vitamin $C$ as dietary supplements or as adjuvant treatments against cancer.

\section{Materials and Methods}

\subsection{Sample Collection}

C. sinuosa samples were collected in July, from the Al Qalamoun area of the North Lebanese coast of the Mediterranean at a depth of 3-5 m. Fresh seaweed was rinsed, air dried, and ground to a fine powder. A voucher specimen (No.20181102A) was deposited in the Doctoral School of Science and Technology, Lebanese University, Tripoli, Lebanon.

\subsection{Extraction of Polysaccharides from C. sinuosa}

C. sinuosa was extracted in absolute ethanol overnight in order to remove pigments, fatty acids, and oligoelements. The mixture was centrifuged at $3000 \mathrm{rpm}$ for $20 \mathrm{~min}$, and the residue was washed thoroughly with ultrapure water. This residue was re-extracted with diluted hydrochloric acid $(\mathrm{HCl} 0.01 \mathrm{M})$ twice at $60^{\circ} \mathrm{C}$ for $3 \mathrm{~h}$ for further depigmentation 
and centrifuged at $3000 \mathrm{rpm}$ for $20 \mathrm{~min}$. The supernatant (1) obtained was used for fucoidan extraction, while the residue (2) was used for the isolation of alginates [47].

\subsubsection{Fucoidan Isolation}

The supernatant (1) was neutralized, rotavapored, and then dialyzed overnight to remove impurities using dialysis cellulose tubing (Sigma, St. Louis, MO, USA, MW cutoff: $1200 \mathrm{KDa}$ ). Dilute $\mathrm{HCl}$ was added to precipitate mannularin and the hydrolysate was centrifuged (3000 rpm, $20 \mathrm{~min}$ ). The obtained residue was discarded, and the supernatant containing the crude fucoidan was lyophilized [47].

\subsubsection{Alginate Isolation}

Residue (2) was extracted with sodium bicarbonate $\left(\mathrm{Na}_{2} \mathrm{CO}_{3}\right)$ for $8 \mathrm{~h}$, diluted to $1.5 \% \mathrm{Na}_{2} \mathrm{CO}_{3}$, and extracted for another $8 \mathrm{~h}$. After centrifugation, the supernatant was rotavapored and dialyzed overnight. Alginic acid was precipitated with ethanol $(1: 1, v / v)$ and again centrifuged to obtain the pellet of interest. This pellet was then dissolved in ultrapure water, and 5 drops of $0.01 \mathrm{M} \mathrm{HCl}$ was added. Sodium alginate was obtained by adding a few drops of $\mathrm{NaOH}$ to reach $\mathrm{pH}$. This process was followed by dialysis and lyophilization to obtain sodium alginate [47].

\subsubsection{Fucoidan and Alginate Purification}

The purification step was adopted and slightly modified from Sari-Chmayssem et al. (2016). Briefly, fucoidan and alginate were dissolved in $0.3 \mathrm{M} \mathrm{HCl}$ and heated at $50{ }^{\circ} \mathrm{C}$ for $3 \mathrm{~h}$. After cooling, the mixture was centrifuged at $5000 \mathrm{rpm}$ for $10 \mathrm{~min}$ and the supernatant was neutralized with $1 \mathrm{M} \mathrm{NaOH}$ and poured over $10 \mathrm{~mL}$ of ethanol. Finally, the precipitate was dissolved and lyophilized [46].

\subsection{Physicochemical Properties}

The yield of each purified polysaccharide was determined by weighing the mass after purification and lyophilization. Next, the total phenolic content (TPC) of each polysaccharide was estimated using the Folin-Ciocalteu method [77]. The absorbance values of polysaccharides were compared with gallic acid standard. The TPC was expressed as mg of gallic acid equivalents (GAE) per gram of powder on a dry weight (DW) basis. The percentage of proteins was estimated using the DC protein Lowry method according to the manufacturer instructions (BioRad kit), with bovine serum albumin used as a standard. The sulfate content was further determined turbidimetrically by adopting the barium chloride-gelatin method and potassium sulfate as a standard [78]. The glucuronic acid content was assessed spectrophotometrically using D-glucuronic acid as the standard [79].

\subsection{Monosaccharide Composition}

For the determination of monosaccharide content by HPLC, fucoidan and alginate were hydrolyzed with $2 \mathrm{M}$ trifluoroacetic acid (TFA) at $121{ }^{\circ} \mathrm{C}$ for $4 \mathrm{~h}$ in glass tubes sealed under nitrogen air. After reaction, the liquid fraction was neutralized to $\mathrm{pH} 7$ and then dried under nitrogen air flow. Samples were then injected into the HPLC system, equipped with a refraction-index (RI) detector. $\mathrm{LC}-\mathrm{NH}_{2}$ column (Sigma) was used for the chromatographic separation of reducing sugars [80]. Glucose, galactose, fucose, mannose, xylose, and arabinose (Sigma) were used as standards.

\subsection{Fourier Transform Infrared Spectroscopy (FTIR) Analysis}

FTIR spectra of fucoidan and alginate were acquired using a SHIMATZU instrument (MIRacle 10 series, total reflectance method). For this analysis, the samples with no additional treatments $(2 \mathrm{mg}$ ) were analyzed. The frequency of the spectra set to analysis was between 4000 and $150 \mathrm{~cm}^{-1}$ wave number, and the vibration spectra were recorded graphically. The $\mathrm{M} / \mathrm{G}$ ratio of alginate was estimated from specific absorption bands at approximately 1030 and $1090 \mathrm{~cm}^{-1}$ [42,81]. 


\subsection{Nuclear Magnetic Resonance (NMR) Spectroscopy}

${ }^{1} \mathrm{H}$ and ${ }^{13} \mathrm{C}$ NMR spectra of alginate and fucoidan were recorded at $70{ }^{\circ} \mathrm{C}$ on a Bruker500 MHz spectrometer. Lyophilized samples of fucoidan and alginate (10 mg, pH 7) were dissolved in deuterium oxide $\left(\mathrm{D}_{2} \mathrm{O}\right)$.

$\mathrm{G}$ and $\mathrm{M}$ quantitative analysis in alginate:

Quantitatively, the mole fraction of $\mathrm{G}$ and the doublet frequency $\mathrm{F}_{\mathrm{GG}}$ are related to the areas (A) of the respective peaks (I, II, and III) by the following relationships [46]:

$$
\begin{aligned}
F G & =\frac{A I}{A I I+A I I I} \\
F G G & =\frac{A I I I}{A I I+A I I I}
\end{aligned}
$$

The mole fraction of $\mathrm{M}$ was then calculated from the equation:

$$
\mathrm{F}_{\mathrm{G}}+\mathrm{F}_{\mathrm{M}}=1
$$

The $\mathrm{M} / \mathrm{G}$ ratio is given by the following:

$$
\frac{\mathrm{M}}{\mathrm{G}}=\frac{(1-\mathrm{FG})}{\mathrm{FG}}
$$

Doublet frequencies ( $\mathrm{F}_{\mathrm{GG}}$ and $\left.\mathrm{F}_{\mathrm{MM}}\right)$ were obtained from the following equations:

$$
\begin{gathered}
\mathrm{F}_{\mathrm{G}}=\mathrm{F}_{\mathrm{GG}}+\mathrm{F}_{\mathrm{GM}} \\
\mathrm{F}_{\mathrm{M}}=\mathrm{F}_{\mathrm{MM}}+\mathrm{F}_{\mathrm{MG}}
\end{gathered}
$$

For high-molecular-weight alginate (DP > 20), we considered that:

$$
\mathrm{F}_{\mathrm{MG}}=\mathrm{F}_{\mathrm{GM}}
$$

\subsection{Preparation of Polysaccharides}

Ultrasound sonication is an effective approach to decrease the viscosity of isolated polysaccharides with minor structural destruction [82]. To reduce the viscosity and molecular weight of the isolated polysaccharides from $C$. sinuosa, fucoidan and alginate stock solutions were prepared and sonicated. They were then dissolved in phosphate buffer saline (PBS 1X) and sonicated in a water bath (Bioruptor ${ }^{\circledR}$ Plus sonication) for $3 \mathrm{~h}$ at $50{ }^{\circ} \mathrm{C}$.

\subsection{Antioxidant Assays}

\subsubsection{DPPH Free Radical Scavenging Assay}

The DPPH antioxidant assay is based on the reduction of DPPH in the presence of a proton-donating compound and is used to evaluate the antioxidant activity of natural compounds [83]. The scavenging effects of samples for DPPH radical were monitored according to the method of a previous report [84]. Fucoidan and alginate were aliquoted into a range of concentrations $\left(100,250,500\right.$, and $\left.750 \mu \mathrm{g} / \mathrm{mL}^{-1}\right)$. The absorbances were measured at $517 \mathrm{~nm}$. All tests were performed in triplicates.

\subsubsection{Superoxide Dismutase (SOD) Inhibition Assay}

SOD is an important antioxidative enzyme which catalyzes the dismutation of the superoxide anion $\left(\mathrm{O}_{2}{ }^{-}\right)$into hydrogen peroxide and oxygen. SOD activity represented the percentage of the inhibition of water-soluble tetrazolium salt (WST-1) [85]. This inhibition was measured in fucoidan and alginate according to the manufacturer instructions using a commercial kit of SOD (19160) (Sigma-Aldrich, St. Louis, USA), and the absorbances were determined at $450 \mathrm{~nm}$. All tests were performed in triplicates. 


\subsection{Cell Lines and Culture}

Human colon cancer (HCT-116), human breast cancer (MCF 7), and human cervical cancer (HeLa) cell lines were purchased from the American Type Culture Collection (ATCC). Cells were cultured in DMEM at $37{ }^{\circ} \mathrm{C}$ in a humidified atmosphere of $5 \% \mathrm{CO}_{2}$ and $95 \%$ air. Media were supplemented with 1\% Penicillin Streptomycin $\left(100 \mu \mathrm{g} / \mathrm{mL}^{-1}\right)$ and $10 \%$ heat-inactivated fetal bovine serum (FBS).

\subsection{Cell Viability Assay}

The cell growth assay is a dimethyl thiazolyldiphenyltetrazolium (MTT)-based method that measures the ability of metabolically active cells to convert tetrazolium salt into a blue formazan product [86]. Cells were seeded in a 96-well plate at a density of $10^{4}$ overnight and then cells were treated with various concentrations of fucoidan and alginate $\left(100-750 \mu \mathrm{g} / \mathrm{mL}^{-1}\right)$. After 24 and $48 \mathrm{~h}$, treatments were removed, and cells were washed prior to MTT incubation for $2 \mathrm{~h}$ at $37^{\circ} \mathrm{C}$. The mean absorbance values of three experiments were expressed as a percentage of viability relative to the control untreated cells. The most sensitive cell line was further subjected to another MTT experiment to test fucoidan and alginate combinations with $5 \mathrm{mM}$ vitamin $C$. The absorbance was recorded at $570 \mathrm{~nm}$.

\subsection{Quantitative Determination of ROS}

Intracellular ROS generation was quantified using CM-H2DCFDA. This method is based on the formation of highly fluorescent $2^{\prime}, 7^{\prime}$-dichlorofluorescein (DCF) from nonfluorescent CM-H2DCFDA. Hydrogen peroxide $\left(20 \mu \mathrm{M} \mathrm{H}_{2} \mathrm{O}_{2}\right)$ was used as a positive control to induce ROS production. Cells were treated with alginate and fucoidan at a concentration of $750 \mu \mathrm{g} / \mathrm{mL}^{-1}$ and incubated for $4 \mathrm{~h}$ at $37^{\circ} \mathrm{C}$. At the end of the treatment period, cells were incubated with $20 \mu \mathrm{M}$ of dye, in a serum and phenol red free medium for $30 \mathrm{~min}$. The fluorescence intensity was detected using a microplate fluorometer TriStar2S LB942 (Brethold, Bad Wildbad, Germany) at an excitation wavelength of $485 \mathrm{~nm}$ and an emission wavelength of $528 \mathrm{~nm}$.

\subsection{Cell Cycle Analysis}

Dead and viable cells were collected $24 \mathrm{~h}$ post-treatment with $750 \mu \mathrm{g} / \mathrm{mL}^{-1}$ of the algal polysaccharides and $5 \mathrm{mM}$ vitamin $\mathrm{C}$ combinations. The pellets were washed with ice-cold PBS, fixed with $70 \%$ ice-cold ethanol, and stored at $-20^{\circ} \mathrm{C}$ overnight. Cells were then washed twice with PBS and incubated with $200 \mu \mathrm{g} / \mathrm{mL}^{-1}$ of RNAse A for $1 \mathrm{~h}$ at $37^{\circ} \mathrm{C}$ before staining with $0.625 \mu \mathrm{g} / \mathrm{mL}^{-1}$ of PI for $30 \mathrm{~min}$. The fluorescence intensity was measured by flow cytometry using a fluorescence-activated cell sorter (FACS) and analyzed using Cell Quest.

\subsection{DAPI Staining}

Morphological changes of the nuclei of treated cells were investigated under a confocal laser scanning microscope using DAPI staining. Briefly, the cells were treated with $750 \mu \mathrm{g} / \mathrm{mL}^{-1}$ of fucoidan, alginate, and their combination with vitamin C. After $24 \mathrm{~h}$, cells were washed with $1 \times$ PBS, then fixed and stored overnight at $-20{ }^{\circ} \mathrm{C}$. Cells were stained with DAPI in the dark. DAPI-stained cells were photographed with a fluorescence microscope using a blue filter (40 and $20 \times$ magnifications).

\subsection{Statistical Analysis}

All statistical analysis ( $t$-test and one-way ANOVA) were performed using GraphPad Prism 7 (version 7.0, GraphPad Software Inc., San Diego, CA, USA). Probability values below $\left.0.05{ }^{*} p<0.05\right)$ were considered significant and values below $0.01\left({ }^{* *} p<0.01\right)$ were considered highly significant. All quantitative variables were reported as mean \pm SD.

Supplementary Materials: Figure S1: Alginate monosaccharide spectrum by HPLC analysis coupled to RI detector, Figure S2: Fucoidan monosaccharide spectrum by HPLC analysis coupled to RI 
detector, Figure S3: Cell cycle gating of HCT-116 treated with fucoidan and alginate isolated from C. sinuosa, together with their combinations with $\mathrm{VC}$, Table S1: ${ }^{1} \mathrm{H}$ and ${ }^{13} \mathrm{C}$ NMR chemical shifts of purified (A) alginate and (B) fucoidan recorded at $70^{\circ} \mathrm{C}$, Table S2: Fucoidan and alginate IC50 against different cancer cell lines (HCT-116, MCF7, and HeLa) at 24 and $48 \mathrm{~h}$.

Author Contributions: R.A.M. and H.M. collected and extracted the algae; H.M., H.G.-M., Z.D. and R.A.M. conceived and designed the research study; R.A.M. mostly performed the experiments; N.S.-C. and R.A.M., intellectual content and literature research; N.S.-C., H.G.-M., R.A.M. and Z.D. analyzed data; R.A.M., H.M. and H.G.-M. prepared and drafted the manuscript; H.G.-M. edited and revised the manuscript; R.A.M., H.G.-M. and Z.D statistical analysis. All authors have read and agreed to the published version of the manuscript.

Funding: This work was funded by the American University of Beirut and Lebanese University.

Institutional Review Board Statement: Not applicable.

Data Availability Statement: All data and materials support our published claims and comply with field standards. Original data could be made available upon request.

Acknowledgments: The authors would like to express gratitude for the Doctoral School for Sciences and Technology for providing many reagents and complete support (Lebanese University, Azm center, Tripoli, Lebanon).

Conflicts of Interest: The authors declare no conflict of interest.

Sample Availability: Samples of the compounds fucoidan and alginateare available from the authors.

\section{References}

1. Khalifa, S.A.M.; Elias, N.; Farag, M.A.; Chen, L.; Saeed, A.; Hegazy, M.-E.F.; Moustafa, M.S.; Abd El-Wahed, A.; Al-Mousawi, S.M.; Musharraf, S.G.; et al. Marine Natural Products: A Source of Novel Anticancer Drugs. Mar. Drugs 2019, 17, 491. [CrossRef]

2. Oliveira, C.; Neves, N.M.; Reis, R.L.; Martins, A.; Silva, T.H. A Review on Fucoidan Antitumor Strategies: From a Biological Active Agent to a Structural Component of Fucoidan-Based Systems. Carbohydr. Polym. 2020, 239, 116131. [CrossRef] [PubMed]

3. Dobrinčić, A.; Balbino, S.; Zorić, Z.; Pedisić, S.; Bursać Kovačević, D.; Elez Garofulić, I.; Dragović-Uzelac, V. Advanced Technologies for the Extraction of Marine Brown Algal Polysaccharides. Mar. Drugs 2020, 18, E168. [CrossRef]

4. Hsu, H.-Y.; Hwang, P.-A. Clinical Applications of Fucoidan in Translational Medicine for Adjuvant Cancer Therapy. Clin. Trans. Med. 2019, 8, 15. [CrossRef] [PubMed]

5. Barbosa, A.I.; Coutinho, A.J.; Costa Lima, S.A.; Reis, S. Marine Polysaccharides in Pharmaceutical Applications: Fucoidan and Chitosan as Key Players in the Drug Delivery Match Field. Mar. Drugs 2019, 17, 654. [CrossRef] [PubMed]

6. Isnansetyo, A.; Lutfia, F.; Nursid, M.; Nursid, M.; Susidarti, R. Cytotoxicity of Fucoidan from Three Tropical Brown Algae against Breast and Colon Cancer Cell Lines. Pharmacogn. J. 2017, 9, 14-20. [CrossRef]

7. Ikeguchi, M.; Yamamoto, M.; Aral, Y.; Maeta, Y.; Ashida, K.; Katano, K.; Miki, Y.; Kimura, T. Fucoidan Reduces the Toxicities of Chemotherapy for Patients with Unresectable Advanced or Recurrent Colorectal Cancer. Oncol. Lett. 2011, 2, 319-322. [CrossRef] [PubMed]

8. Burney, M.; Mathew, L.; Gaikwad, A.; Nugent, E.K.; Gonzalez, A.O.; Smith, J.A. Evaluation Fucoidan Extracts From Undaria Pinnatifida and Fucus Vesiculosus in Combination With Anticancer Drugs in Human Cancer Orthotopic Mouse Models. Integr. Cancer Ther. 2018, 17, 755-761. [CrossRef]

9. Oh, B.; Kim, J.; Lu, W.; Rosenthal, D. Anticancer Effect of Fucoidan in Combination with Tyrosine Kinase Inhibitor Lapatinib. Evid.-Based Complement. Altern. Med. 2014, 2014, 865375. [CrossRef]

10. Fernando, I.P.S.; Kim, D.; Nah, J.-W.; Jeon, Y.-J. Advances in Functionalizing Fucoidans and Alginates (Bio)Polymers by Structural Modifications: A Review. Chem. Eng. 2019, 355, 33-48. [CrossRef]

11. Gomaa, M.; Hifney, A.; Fawzy, M.; Abdel-Gawad, K. Use of Seaweed and Filamentous Fungus Derived Polysaccharides in the Development of Alginate-Chitosan Edible Films Containing Fucoidan: Study of Moisture Sorption, Polyphenol Release and Antioxidant Properties. Food Hydrocoll. 2018, 82, 239-247. [CrossRef]

12. Rhein-Knudsen, N.; Ale, M.; Ajalloueian, F.; Meyer, A. Characterization of Alginates from Ghanaian Brown Seaweeds: Sargassum spp. and Padina spp. Food Hydrocoll. 2017, 71, 236-244. [CrossRef]

13. Das, R.K.; Kasoju, N.; Bora, U. Encapsulation of Curcumin in Alginate-Chitosan-Pluronic Composite Nanoparticles for Delivery to Cancer Cells. Nanomed. Nanotechnol. Biol. Med. 2010, 6, 153-160. [CrossRef]

14. Ivanovska, J.; Zehnder, T.; Lennert, P.; Sarker, B.; Boccaccini, A.R.; Hartmann, A.; Schneider-Stock, R.; Detsch, R. Biofabrication of 3D Alginate-Based Hydrogel for Cancer Research: Comparison of Cell Spreading, Viability, and Adhesion Characteristics of Colorectal HCT116 Tumor Cells. Tissue Eng. Part C Methods 2016, 22, 708-715. [CrossRef] [PubMed] 
15. Sorasitthiyanukarn, F.N.; Muangnoi, C.; Bhuket, P.R.N.; Rojsitthisak, P.; Rojsitthisak, P. Pranee Chitosan/Alginate Nanoparticles as a Promising Approach for Oral Delivery of Curcumin Diglutaric Acid for Cancer Treatment. Mater. Sci. Eng. C 2018, 93, 178-190. [CrossRef]

16. Szekalska, M.; Puciłowska, A.; Szymańska, E.; Ciosek, P.; Winnicka, K. Alginate: Current Use and Future Perspectives in Pharmaceutical and Biomedical Applications. Int. J. Polym. Sci. 2016, 2016, 7697031. [CrossRef]

17. Olukman, M.; Oya, S.; Solak, E.K. Release of Anticancer Drug 5-Fluorouracil from Different Ionically Crosslinked Alginate Beads. J. Biomater. Nanobiotechnol. 2012, 3, 469. [CrossRef]

18. Rahaiee, S.; Hashemi, M.; Shojaosadati, S.A.; Moini, S.; Razavi, S.H. Nanoparticles Based on Crocin Loaded Chitosan-Alginate Biopolymers: Antioxidant Activities, Bioavailability and Anticancer Properties. Int. J. Biol. Macromol. 2017, 99, 401-408. [CrossRef]

19. Rezk, A.I.; Obiweluozor, F.O.; Choukrani, G.; Park, C.H.; Kim, C.S. Drug Release and Kinetic Models of Anticancer Drug (BTZ) from a PH-Responsive Alginate Polydopamine Hydrogel: Towards Cancer Chemotherapy. Int. J. Biol. Macromol. 2019, 141, 388-400. [CrossRef]

20. Sánchez, B.G.; Bort, A.; Mateos-Gómez, P.A.; Rodríguez-Henche, N.; Díaz-Laviada, I. Combination of the Natural Product Capsaicin and Docetaxel Synergistically Kills Human Prostate Cancer Cells through the Metabolic Regulator AMP-Activated Kinase. Cancer Cell Int. 2019, 19, 54. [CrossRef] [PubMed]

21. Wilson, M.K.; Baguley, B.C.; Wall, C.; Jameson, M.B.; Findlay, M.P. Review of High-Dose Intravenous Vitamin C as an Anticancer Agent. Asia Pac. J. Clin. Oncol. 2014, 10, 22-37. [CrossRef] [PubMed]

22. De Francesco, E.M.; Bonuccelli, G.; Maggiolini, M.; Sotgia, F.; Lisanti, M.P. Vitamin C and Doxycycline: A Synthetic Lethal Combination Therapy Targeting Metabolic Flexibility in Cancer Stem Cells (CSCs). Oncotarget 2017, 8, 67269-67286. [CrossRef] [PubMed]

23. Mostafavi-Pour, Z.; Ramezani, F.; Keshavarzi, F.; Samadi, N. The Role of Quercetin and Vitamin C in Nrf2-dependent Oxidative Stress Production in Breast Cancer Cells. Oncol. Lett. 2017, 13, 1965-1973. [CrossRef] [PubMed]

24. Men'shova, R.V.; Ermakova, S.P.; Rachidi, S.M.; Al-Hajje, A.H.; Zvyagintseva, T.N.; Kanaan, H.M. Seasonal Variations of the Composition, Structural Features, and Antitumor Properties of Polysaccharides from Padina Pavonica (Lebanon) as a Function of Composition. Chem. Nat. Compd. 2012, 47, 870-875. [CrossRef]

25. Tannoury, M.; Khayrallah, M.; Saab, A.M.; Diab-Assaf, M.; Rizk, F.; Hamade, A.; Najjar, F. Evaluation of Cytotoxic Activity of Chorda Filum from the Lebanese Coast against MCF-7 Cancer Cell Line. Eur. J. Biomed. 2018, 5, 56-62.

26. Tannoury, M.; Saab, A.M.; Elia, J.M.; Makhlouf, H.; Diab-Assaf, M. In Vitro Cytotoxic Activity of Laurencia Papillosa, Marine Red Algae from the Lebanese Coast. J. Appl. Pharm. Sci. 2017, 7, 175-179.

27. Tannoury, M.; Elia, J.M.; Saab, A.M.; Makhlouf, H.; Daouchabo, R.; Diab-Assaf, M. Evaluation of Cytotoxic Activity of Sargassum Vulgare from the Lebanese Coast Against Jurkat Cancer Cell Line. J. Appl. Pharm. Sci. 2016, 6, 108-112. [CrossRef]

28. Al Monla, R.; Dessouki, Z.; Gali-Muhtasib, H.; Mawalwi, H. Chemical Analysis and Biological Potentials of Extracts from Colpomenia Sinuosa. Pharmacogn. Res. 2020, 12, 272-277.

29. Hernández-Garibay, E.; Zertuche-González, J.A.; Pacheco-Ruiz, I. Sulfated Polysaccharides (Fucoidan) from the Brown Seaweed Silvetia Compressa (J. Agardh) E. Serrão, TO Cho, SM Boo \& Brawley. J. Appl. Phycol. 2019, 31, 3841-3847. [CrossRef]

30. Grasdalen, H. High-Field, 1HNMR Spectroscopy of Alginate: Sequential Structure and Linkage Conformations. Carbohydr. Res. 1983, 118, 255-260. [CrossRef]

31. Davis, T.A.; Llanes, F.; Volesky, B.; Mucci, A. Metal Selectivity of Sargassum Spp. and Their Alginates in Relation to Their

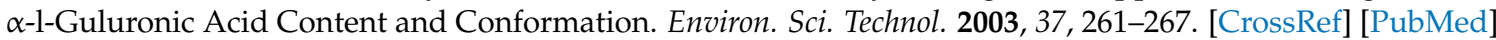

32. Davis, T.A.; Llanes, F.; Volesky, B.; Diaz-Pulido, G.; McCook, L.; Mucci, A. 1H-NMR Study of Na Alginates Extracted from Sargassum Spp. in Relation to Metal Biosorption. Appl. Biochem. Biotechnol. 2003, 110, 75-90. [CrossRef]

33. Diniz do Nascimento, L.; Moraes, A.A.B.; Costa, K.S.D.; Pereira Galúcio, J.M.; Taube, P.S.; Costa, C.M.L.; Neves Cruz, J.; de Aguiar Andrade, E.H.; Faria, L.J.G.D. Bioactive Natural Compounds and Antioxidant Activity of Essential Oils from Spice Plants: New Findings and Potential Applications. Biomolecules 2020, 10, 988. [CrossRef]

34. Kedare, S.B.; Singh, R.P. Genesis and Development of DPPH Method of Antioxidant Assay. J. Food Sci. Technol. $2011,48,412-422$. [CrossRef]

35. Yamanaka, Y.; Yoshida-Yamamoto, S.; Doi, H. Microtubule Formation and Activities of Antioxidative Enzymes in PC12 Cells Exposed to Phosphatidylcholine Hydroperoxides. Int. J. Mol. Sci. 2012, 13, 15510-15522. [CrossRef]

36. Perillo, B.; Donato, M.D.; Pezone, A.; Zazzo, E.D.; Giovannelli, P.; Galasso, G.; Castoria, G.; Migliaccio, A. ROS in Cancer Therapy: The Bright Side of the Moon. Exp. Mol. Med. 2020, 52, 192-203. [CrossRef] [PubMed]

37. Wen, S.; Wang, Z.-H.; Zhang, C.-X.; Yang, Y.; Fan, Q.-L. Caspase-3 Promotes Diabetic Kidney Disease Through Gasdermin E-Mediated Progression to Secondary Necrosis During Apoptosis. Diabetes Metab. Syndr. Obes. Targets Ther. 2020, 13, $313-323$. [CrossRef]

38. Sanjeewa, K.K.A.; Kang, N.; Ahn, G.; Jee, Y.; Kim, Y.-T.; Jeon, Y.-J. Bioactive Potentials of Sulfated Polysaccharides Isolated from Brown Seaweed Sargassum Spp in Related to Human Health Applications: A Review. Food Hydrocoll. 2018, 81, 200-208. [CrossRef]

39. Al Monla, R.; Dassouki, Z.; Kouzayha, A.; Salma, Y.; Gali-Muhtasib, H.; Mawlawi, H. The Cytotoxic and Apoptotic Effects of the Brown Algae Colpomenia Sinuosa Are Mediated by the Generation of Reactive Oxygen Species. Molecules 2020, $25,1993$. [CrossRef] 
40. Arumugam, P.; Arunkumar, K.; Sivakumar, L.; Murugan, M.; Murugan, K. Anticancer Effect of Fucoidan on Cell Proliferation, Cell Cycle Progression, Genetic Damage and Apoptotic Cell Death in HepG2 Cancer Cells. Toxicol. Rep. 2019, 6, 556-563. [CrossRef]

41. Mathlouthi, M.; Koenig, J.L. Vibrational Spectra of Carbohydrates. Adv. Carbohydr. Chem. Biochem. 1986, 44, 7-89. [CrossRef]

42. Leal, D.; Matsuhiro, B.; Rossi, M.; Caruso, F. FT-IR Spectra of Alginic Acid Block Fractions in Three Species of Brown Seaweeds. Carbohydr. Res. 2008, 343, 308-316. [CrossRef]

43. Sinha, S.; Astani, A.; Ghosh, T.; Schnitzler, P.; Ray, B. Polysaccharides from Sargassum Tenerrimum: Structural Features, Chemical Modification and Anti-Viral Activity. Phytochemistry 2010, 71, 235-242. [CrossRef]

44. Zhang, Z.; Lin, T.; Li, S.; Chen, X.; Que, X.; Sheng, L.; Hu, Y.; Peng, J.; Ma, H.; Li, J.; et al. Polyacrylamide/Copper-Alginate Double Network Hydrogel Electrolyte with Excellent Mechanical Properties and Strain-Sensitivity. Macromol. Biosci. 2021, 578, 2100361. [CrossRef]

45. Hilbig, J.; Hartlieb, K.; Gibis, M.; Herrmann, K.; Weiss, J. Rheological and Mechanical Properties of Alginate Gels and Films Containing Different Chelators. Food Hydrocoll. 2020, 101, 105487. [CrossRef]

46. Sari-Chmayssem, N.; Taha, S.; Mawlawi, H.; Guégan, J.-P.; Jeftić, J.; Benvegnu, T. Extracted and Depolymerized Alginates from Brown Algae Sargassum Vulgare of Lebanese Origin: Chemical, Rheological, and Antioxidant Properties. J. Appl. Phycol. 2016, 28, 1915-1929. [CrossRef]

47. Haddad, M.; Zein, S.; Hazeime, G.; Krivoruchko, E.; Makhour, Y.; Kassem, Z.; Kanaan, H. Structural Characteristics, Antitumor and Antioxidant Properties of Polysaccharides Isolated from the Brown Algae Stypopodium schimperi Growing on the Lebanese Coast. ARJMD 2017, 17, 36-43.

48. Magalhaes, K.D.; Costa, L.S.; Fidelis, G.P.; Oliveira, R.M.; Nobre, L.T.D.B.; Dantas-Santos, N.; Camara, R.B.G.; Albuquerque, I.R.L.; Cordeiro, S.L.; Sabry, D.A.; et al. Anticoagulant, Antioxidant and Antitumor Activities of Heterofucans from the Seaweed Dictyopteris delicatula. Int. J. Mol. Sci. 2011, 12, 3352-3365. [CrossRef] [PubMed]

49. Usov, A.; Bilan, M.I. Fucoidans-Sulfated Polysaccharides of Brown Algae. Russ. Chem. Rev. 2009, 78, 785-799. [CrossRef]

50. Yu, P.; Sun, H. Purification of a Fucoidan from Kelp Polysaccharide and Its Inhibitory Kinetics for Tyrosinase. Carbohydr. Polym. 2014, 99, 278-283. [CrossRef] [PubMed]

51. Thangapandi, M.; Ajithkumar, T.; Shanmugaasokan, L.; Suja, G.; Thirumalairaj, V. In Vitro Anticancer Activity of Fucoidan from Turbinaria Conoides against A549 Cell Lines. Int. J. Biol. Macromol. 2014, 72, 919-923. [CrossRef]

52. Sinurat, E.; Saefudin, E.; Peranginangin, R.; Pws, S.H. Immunostimulatory Activity of Brown Seaweed-Derived Fucoidans at Different Molecular Weights and Purity Levels towards White Spot Syndrome Virus (WSSV) in Shrimp Litopenaeus vannamei. J. Appl. Pharm. Sci. 2016, 6, 82-91. [CrossRef]

53. Alwarsamy, M.; Gooneratne, R.; Ravichandran, R. Effect of Fucoidan from Turbinaria Conoides on Human Lung Adenocarcinoma Epithelial (A549) Cells. Carbohydr. Polym. 2016, 152, 207-213. [CrossRef]

54. Ptak, S.H.; Fretté, X.C. Algae Polysaccharides as Nutraceuticals: Isolation, Characterization and Bioactivities of Fucoidans. In Algae for Food; CRC Press: Boca Raton, FL, USA, 2021; ISBN 978-1-00-316594-1.

55. Szabó, L.; Gerber-Lemaire, S.; Wandrey, C. Strategies to Functionalize the Anionic Biopolymer Na-Alginate without Restricting Its Polyelectrolyte Properties. Polymers 2020, 12, 919. [CrossRef]

56. Shao, L.; Sun, Y.; Liang, J.; Li, M.; Li, X. Decolorization Affects the Structural Characteristics and Antioxidant Activity of Polysaccharides from Thesium Chinense Turcz: Comparison of Activated Carbon and Hydrogen Peroxide Decolorization. Int. J. Biol. Macromol. 2020, 155, 1084-1091. [CrossRef] [PubMed]

57. Chen, C.-Y.; Wang, S.-H.; Huang, C.-Y.; Dong, C.-D.; Huang, C.-Y.; Chang, C.-C.; Chang, J.-S. Effect of Molecular Mass and Sulfate Content of Fucoidan from Sargassum Siliquosum on Antioxidant, Anti-Lipogenesis, and Anti-Inflammatory Activity. J. Biosci. Bioeng. 2021, 132, 359-364. [CrossRef] [PubMed]

58. Lutfia, F.N.L.; Isnansetyo, A.; Susidarti, R.A.; Nursid, M. Chemical Composition Diversity of Fucoidans Isolated from Three Tropical Brown Seaweeds (Phaeophyceae) Species. Biodiversitas J. Biol. Divers. 2020, 21, 3170-3177. [CrossRef]

59. Palanisamy, S.; Vinosha, M.; Marudhupandi, T.; Rajasekar, P.; Prabhu, N.M. In Vitro Antioxidant and Antibacterial Activity of Sulfated Polysaccharides Isolated from Spatoglossum Asperum. Carbohydr Polym. 2017, 170, 296-304. [CrossRef]

60. Liu, J.; Wu, S.-Y.; Chen, L.; Li, Q.-J.; Shen, Y.-Z.; Jin, L.; Zhang, X.; Chen, P.-C.; Wu, M.-J.; Choi, J.; et al. Different Extraction Methods Bring About Distinct Physicochemical Properties and Antioxidant Activities of Sargassum Fusiforme Fucoidans. Int. J. Biol. Macromol. 2010, 155, 1385-1392. [CrossRef]

61. Kurnialahi, I.D.; Husni, A.; Sinurat, E.; Isnansetyo, A. Antioxidant Activity of Tropical Seaweed Sargassum Muticum Fucoidan. Aquac. Aquar. Conserv. Legis. 2020, 13, 230-240.

62. Wang, S.-H.; Huang, C.-Y.; Chen, C.-Y.; Chang, C.-C.; Huang, C.-Y.; Dong, C.-D.; Chang, J.-S. Structure and Biological Activity Analysis of Fucoidan Isolated from Sargassum siliquosum. ACS Omega 2020, 5, 32447-32455. [CrossRef]

63. Kim, E.J.; Park, S.Y.; Lee, J.-Y.; Park, J.H.Y. Fucoidan Present in Brown Algae Induces Apoptosis of Human Colon Cancer Cells. BMC Gastroenterol. 2010, 10, 96. [CrossRef]

64. Sokolova, R.V.; Ermakova, S.P.; Awada, S.M.; Zvyagintseva, T.N.; Kanaan, H.M. Composition, Structural Characteristics, and Antitumor Properties of Polysaccharides from the Brown Algae Dictyopteris Polypodioides and Sargassum sp. Chem. Nat. Compd. 2011, 47, 329-334. [CrossRef] 
65. Yang, L.; Wang, P.; Wang, H.; Li, Q.; Teng, H.; Liu, Z.; Yang, W.; Hou, L.; Zou, X. Fucoidan Derived from Undaria Pinnatifida Induces Apoptosis in Human Hepatocellular Carcinoma SMMC-7721 Cells via the ROS-Mediated Mitochondrial Pathway. Mar. Drugs 2013, 11, 1961-1976. [CrossRef]

66. Wei, C.; Xiao, Q.; Kuang, X.; Zhang, T.; Yang, Z.; Wang, L. Fucoidan Inhibits Proliferation of the SKM-1 Acute Myeloid Leukaemia Cell Line via the Activation of Apoptotic Pathways and Production of Reactive Oxygen Species. Mol. Med. Rep. 2015, 12, 6649-6655. [CrossRef]

67. Han, M.H.; Lee, D.-S.; Jeong, J.-W.; Hong, S.-H.; Choi, I.-W.; Cha, H.-J.; Kim, S.; Kim, H.-S.; Park, C.; Kim, G.-Y.; et al. Fucoidan Induces ROS-Dependent Apoptosis in 5637 Human Bladder Cancer Cells by Downregulating Telomerase Activity via Inactivation of the PI3K/Akt Signaling Pathway. Drug Dev. Res. 2017, 78, 37-48. [CrossRef] [PubMed]

68. Narayani, S.S.; Saravanan, S.; Ravindran, J.; Ramasamy, M.S.; Chitra, J. In Vitro Anticancer Activity of Fucoidan Extracted from Sargassum Cinereum against Caco-2 Cells. Int. J. Biol. Macromol. 2019, 138, 618-628. [CrossRef]

69. Zhou, L.; Yi, Y.; Yuan, Q.; Zhang, J.; Li, Y.; Wang, P.; Xu, M.; Xie, S. VAOS, a Novel Vanadyl Complexes of Alginate Saccharides, Inducing Apoptosis via Activation of AKT-Dependent ROS Production in NSCLC. Free Radic. Biol. Med. 2018, 129, 177-185. [CrossRef] [PubMed]

70. Ibrahim, O.M.; El-Deeb, N.M.; Abbas, H.; Elmasry, S.M.; El-Aassar, M.R. Alginate Based Tamoxifen/Metal Dual Core-Folate Decorated Shell: Nanocomposite Targeted Therapy for Breast Cancer via ROS-Driven NF-KB Pathway Modulation. Int. J. Biol. Macromol. 2020, 146, 119-131. [CrossRef]

71. Laurienzo, P. Marine Polysaccharides in Pharmaceutical Applications: An Overview. Mar. Drugs 2010, 8, 2435-2465. [CrossRef]

72. Saitoh, Y.; Nagai, Y.; Miwa, N. Fucoidan-Vitamin C Complex Suppresses Tumor Invasion through the Basement Membrane, with Scarce Injuries to Normal or Tumor Cells, via Decreases in Oxidative Stress and Matrix Metalloproteinases. Int. J. Oncol. 2009, 35, 1183-1189. [CrossRef]

73. Park, H.Y.; Kim, G.-Y.; Moon, S.-K.; Kim, W.J.; Yoo, Y.H.; Choi, Y.H. Fucoidan Inhibits the Proliferation of Human Urinary Bladder Cancer T24 Cells by Blocking Cell Cycle Progression and Inducing Apoptosis. Molecules 2014, 19, 5981-5998. [CrossRef]

74. Singh, T.R.; Ezhilarasan, D. Ethanolic Extract of Lagerstroemia Speciosa (L.) Pers., Induces Apoptosis and Cell Cycle Arrest in HepG2 Cells. Nutr. Cancer 2020, 72, 146-156. [CrossRef] [PubMed]

75. Atashrazm, F.; Lowenthal, R.M.; Woods, G.M.; Holloway, A.F.; Dickinson, J.L. Fucoidan and Cancer: A Multifunctional Molecule with Anti-Tumor Potential. Mar. Drugs 2015, 13, 2327-2346. [CrossRef]

76. Park, H.Y.; Park, S.-H.; Jeong, J.-W.; Yoon, D.; Han, M.H.; Lee, D.-S.; Choi, G.; Yim, M.-J.; Lee, J.M.; Kim, D.-H.; et al. Induction of P53-Independent Apoptosis and G1 Cell Cycle Arrest by Fucoidan in HCT116 Human Colorectal Carcinoma Cells. Mar. Drugs 2017, 15, 154. [CrossRef]

77. Dahmoune, F.; Nayak, B.; Moussi, K.; Remini, H.; Madani, K. Optimization of Microwave-Assisted Extraction of Polyphenols from Myrtus Communis L. Leaves. Food Chem. 2015, 166, 585-595. [CrossRef]

78. Dodgson, K.S.; Price, R.G. A Note on the Determination of the Ester Sulphate Content of Sulphated Polysaccharides. Biochem. J. 1962, 84, 106-110. [CrossRef] [PubMed]

79. Saboural, P.; Chaubet, F.; Rouzet, F.; Al-Shoukr, F.; Azzouna, R.B.; Bouchemal, N.; Picton, L.; Louedec, L.; Maire, M.; Rolland, L.; et al. Purification of a Low Molecular Weight Fucoidan for SPECT Molecular Imaging of Myocardial Infarction. Mar. Drugs 2014, 12, 4851-4867. [CrossRef]

80. Sułkowska-Ziaja, K.; Muszyńska, B.; Ekiert, H. Chemical Composition and Cytotoxic Activity of the Polysaccharide Fractions in Sarcodon Imbricatus (Basidiomycota). Acta Mycol. 2013, 47, 49-56. [CrossRef]

81. Gómez-Ordóñez, E.; Rupérez, P. FTIR-ATR Spectroscopy as a Tool for Polysaccharide Identification in Edible Brown and Red Seaweeds. Food Hydrocoll. 2011, 25, 1514-1520. [CrossRef]

82. Guo, X.; Ye, X.; Sun, Y.; Wu, D.; Wu, N.; Hu, Y.; Chen, S. Ultrasound Effects on the Degradation Kinetics, Structure, and Antioxidant Activity of Sea Cucumber Fucoidan. J. Agric. Food Chem. 2014, 62, 1088-1095. [CrossRef]

83. Wang, L.; Xiao, R.; Mo, J. Quantitative Detection Method of Semiquinone Free Radicals on Particulate Matters Using Electron Spin Resonance Spectroscopy. Sustain. Cities Soc. 2019, 49, 101614. [CrossRef]

84. Yen, G.-C.; Chen, H.-Y. Antioxidant Activity of Various Tea Extracts in Relation to Their Antimutagenicity. J. Agric. Food Chem. 1995, 43, 27-32. [CrossRef]

85. Elansary, H.O.; Yessoufou, K.; Abdel-Hamid, A.M.E.; El-Esawi, M.A.; Ali, H.M.; Elshikh, M.S. Seaweed Extracts Enhance Salam Turfgrass Performance during Prolonged Irrigation Intervals and Saline Shock. Front. Plant Sci. 2017, 8, 14. [CrossRef] [PubMed]

86. Luis, C.; Castaño-Guerrero, Y.; Soares, R.; Sales, G.; Fernandes, R. Avoiding the Interference of Doxorubicin with MTT Measurements on the MCF-7 Breast Cancer Cell Line. Methods Protoc. 2019, 2, 29. [CrossRef] 